\title{
FAKTOR RISIKO HIPEREMESIS GRAVIDARUM PADA IBU HAMIL DI SEMARANG
}

\author{
Annisa Dinah Nurbaity, Aryu Candra, Deny Yudi Fitranti* \\ Departemen Ilmu Gizi, Fakultas Kedokteran, Universitas Diponegoro \\ J1. Prof. Sudarto SH, Tembalang, Semarang, Jawa Tengah 50275, Indonesia \\ *Penulis Penanggungjawab. E-mail: denyyudi@gmail.com
}

\begin{abstract}
Background: Hyperemesis gravidarum is nausea and vomiting that occurs in pregnant women with a frequency of more than 3 times and continuously. Hyperemesis occurs in 0.5 to $2 \%$ of pregnancies. Hyperemesis occurs as an interaction between biological, psychological, and sociocultural factors. Hyperemesis most occurs in the 1st trimester, but can continue in the 2nd trimester. Hyperemesis if left untreated can interferewith women's health and her baby.

Method: Case control study with 44 subjects taken by purposive sampling. Body Mass Index (BMI) data was obtained through anthropometric measurements, intake data was obtained by using Semi Quantitative Food Frequency Questionnaire. Bivariate analysis using Chi square and Fisher Exact test.

Results: The percentage of carbohydrate and saturated fat intake were higher in the women with hyperemesis group $(4,5 \% ; 18,18 \%)$ than without hyperemesis group $(0 \% ; 4,5 \%)$. There was no significant association between prepregnancy Body Mass Index (BMI), intake of carbohydrate, protein, saturated fat, omega 3 fatty acid, omega 6 fatty acid, and vitamin $B 6$ in relation to hyperemesis gravidarum $(p>0,05)$.

Conclusion: Nutritional status before pregnancy, carbohydrate, protein, saturated fat, omega 3 fatty acids, omega 6 fatty acids, and vitamin B6 intake are not risk factors for hyperemesis gravidarum in pregnant women in Semarang.
\end{abstract}

Keywords: Hyperemesis gravidarum; body mass index; food intake; pregnancy

\begin{abstract}
ABSTRAK
Latar belakang: Hiperemesis gravidarum adalah mual muntah yang terjadi pada ibu hamil dengan frekuensi lebih dari 3 kali dalam satu hari dan terjadi terus menerus. Hiperemesis terjadi pada 0,5 hingga 2\% kehamilan. Hiperemesis terjadi sebagai interaksi antara faktor biologis, psikologis, dan sosiokultural. Hiperemesis paling banyak terjadi pada trimester 1, namun dapat berlanjut pada trimester 2. Hiperemesis jika tidak ditangani dapat menyebabkan gangguan pada ibu hamil dan janin.

Metode: Penelitian ini menggunakan rancangan case control dengan subjek 44 ibu hamil yang diambil dengan cara purposive sampling. Data indeks massa tubuh (IMT) didapatkan melalui pengukuran antropometri, data asupan diperoleh melalui wawancara semi-quantitative food frequency questionnaire. Analisis bivariat menggunakan uji chi square dan fisher exact.

Hasil: Persentase asupan karbohidrat dan lemak jenuh lebih tinggi pada kelompok hiperemesis (4,5\% ; 18,18\%) daripada kelompok tanpa hiperemesis (0\%; 4,5\%). Tidak ada hubungan yang signifikan antara status gizi sebelum kehamilan, asupan karbohidrat, protein, lemak jenuh, asam lemak omega 3, asam lemak omega 6, dan vitamin B6 dengan hiperemesis gravidarum ( $p>0,05)$

Simpulan: Status gizi sebelum hamil, asupan karbohidrat, protein, lemak jenuh, asam lemak omega 3, asam lemak omega 6, dan vitamin B6 bukan merupakan faktor risiko terjadinya hiperemesis gravidarum pada ibu hamil di Semarang.
\end{abstract}

Kata Kunci: Hiperemesis gravidarum; indeks massa tubuh; asupan; kehamilan

\section{PENDAHULUAN}

Hiperemesis gravidarum (HG) merupakan komplikasi kehamilan yang ditandai dengan mual dan muntah secara terus menerus yang dapat menyebabkan penurunan berat badan lebih dari 5\% dari berat badan sebelum hamil, dehidrasi, asidosis metabolik akibat kelaparan, alkalosis akibat kehilangan asam klorida, dan hipokalemia. Hiperemesis biasanya mulai terjadi pada kehamilan minggu ke 4 hingga minggu ke 6 , kemudian tingkat keparahan meningkat pada minggu ke 8 hingga minggu ke 12 , dan biasanya berakhir pada minggu ke 20. ${ }^{1,2}$ Mual dan muntah tersebut biasanya hilang setelah trimester pertama. ${ }^{1}$ Hiperemesis diperkirakan terjadi pada 5 per 1000 kehamilan. Menurut sumber lain hiperemesis gravidarum terjadi pada $0.5 \%$ hingga $2 \%$ kehamilan. $^{3}$

Hiperemesis gravidarum dapat terjadi sebagai interaksi antara faktor biologis, psikologis, dan sosiokultural. Diduga bahwa wanita yang memiliki indeks massa tubuh rendah memiliki tingkat estrogen sebelum hamil yang rendah dan 
memiliki respons berlebihan terhadap peningkatan kadar estrogen selama trimester pertama. ${ }^{4}$ Estrogen sendiri memiliki banyak efek pada saluran gastrointestinal (GI). Tingginya kadar estrogen menyebabkan waktu transit usus lebih lambat dan dapat menghambat pengosongan lambung. ${ }^{5}$

Hiperemesis gravidarum juga dapat dipengaruhi oleh beberapa asupan diantaranya adalah asupan karbohidrat, asupan protein, asupan lemak jenuh, asupan asam lemak omega-3, asupan asam lemak omega-6, dan asupan vitamin B6. Asupan karbohidrat, protein dan lemak dapat mempengaruhi irama lambung normal sehingga menimbulkan disritmia lambung yang berdampak pada terjadinya mual muntah. Beberapa hasil penelitian menunjukkan bahwa konsumsi karbohidrat dalam jumlah banyak berhubungan dengan kejadian mual dan muntah pada ibu hamil. ${ }^{6,7}$

Adanya pembentukan sel baru akan mendorong permintaan protein dalam waktu cepat dan akan membutuhkan peningkatan jumlah protein baik dari cadangan maupun dari makanan. Hal ini dapat menyebabkan tubuh mengalami defisiensi protein apabila kebutuhan protein tidak terpenuhi. Kekurangan protein dalam waktu cepat akan menyebabkan disritmia lambung dan menimbulkan perasaan mual. ${ }^{8}$ Selain itu, konsumsi protein dalam jumlah cukup dapat merangsang sekresi gastrin yang dapat berperan dalam mempertahankan irama lambung. ${ }^{9}$

Hiperemesis juga dikaitkan dengan asupan lemak. Peningkatan lemak tubuh diyakini dapat menyebabkan peningkatan produksi estrogen. ${ }^{10}$ Meningkatnya kadar estrogen berkaitan dengan terjadinya hiperemesis gravidarum. ${ }^{11}$ Selain itu, makanan yang berlemak dapat menunda pengosongan lambung yang mengakibatkan terjadinya mual. Lemak dapat menghambat pelepasan gastrin di dalam perut dan dapat mempengaruhi aktivitas ritmis lambung. Lemak juga dapat menghambat protein dalam mempertahankan aktivitas lambung secara normal. ${ }^{12}$

Hiperemesis juga berkaitan dengan asupan asam lemak omega 3. Eicosapentaenoic acid (EPA) dan docosahexaenoicacid (DHA) merupakan komponen bioaktif utama asam lemak tak jenuh omega-3. Kekurangan DHA berkaitan dengan disfungsi stabilitas membran neuron dan transmisi serotonin, norepinefrin, dan dopamin, yang berhubungan dengan penyebab mood dan disfungsi kognitif. Serotonin juga berperan dalam mencegah terjadinya mual dan muntah. Selain itu, EPA juga penting untuk menyeimbangkan fungsi kekebalan dan kesehatan fisik dengan menekan efek proinflamasi asam arakhidonat (asam lemak tak jenuh omega-6) sehingga mengurangi sintesis prostaglandin E2, yang berkaitan dengan depresi. Sebaliknya, asam arakhidonat (AA), asam lemak tak jenuh omega-6, merupakan substrat utama untuk prostaglandin E2. Diet tinggi AA dapat meningkatkan glukokortikoid dan prostglandain E2 serta kecemasan. ${ }^{13}$ Prostaglandin E2 dinilai turut berperan dalam patogenesis mual dan muntah pada ibu hamil karena efeknya pada kontraksi otot polos longitudinal dan relaksasi otot polos melingkar.

Vitamin B6 dapat berperan sebagai koenzim yang memungkinkan terjadinya reaktivitas lisin, dimana reaktivitas lisin tersebut dapat mengurangi mual dan muntah yang disebabkan oleh meningkatnya kadar estrogen pada ibu hamil. Vitamin B6 juga dianggap berperan dalam sintetis serotonin, dopamin, norepinefrin, dan asam gamma amino butirat dengan mengkatalisis proses dekarboksilasi. Kekurangan asam gamma amino butirat dapat menyebabkan mual dan muntah pada kehamilan. ${ }^{14}$ Oleh karena itu, penelitian ini bertujuan untuk mengetahui besar risiko status gizi sebelum hamil, asupan karbohidrat, protein, lemak jenuh, asam lemak omega 3, asam lemak omega 6 dan vitamin B6 terhadap kejadian hiperemesis pada ibu hamil di Semarang.

\section{METODE}

Penelitian ini termasuk dalam lingkup penelitian gizi masyarakat dan merupakan penelitian observasional dengan desain case control yang dilaksanakan pada bulan Juli-November 2018. Penelitian dilakukan di wilayah kerja Puskesmas Halmahera, Puskesmas Tlogosari Wetan, dan Puskesmas Kedungmundu. Populasi terjangkau dalam penelitian ini adalah ibu hamil berusia 20-35 tahun dengan usia kehamilan berada di trimester 1 dan 2 yang bertempat tinggal di wilayah kerja Puskesmas Halmahera, Puskesmas Tlogosari Wetan dan Puskesmas Kedungmundu.

Besar sampel dihitung dengan rumus besar sampel untuk uji analitik kategorik dengan tingkat kesalahan tipe I ( $\mathrm{Z} \alpha 5 \%$ dan tingkat kesalahan tipe II (ZB) $20 \%$ serta proporsi minimal yang dianggap bermakna $0,2^{15}$, sehingga diperoleh hasil perhitungan sampel minimal sebanyak 22 orang ditambah dengan $10 \%$ formula koreksi dan menghasilkan jumlah sampel sebesar 25 orang. Kriteria inklusi pemilihan sampel meliputi ibu hamil berusia 20-35 tahun, usia kehamilan trimester 1 dan 2, jumlah janin yang dikandung berjumlah satu (tunggal), dapat berkomunikasi dengan baik, tinggal di wiayah kerja puskesmas, tidak memiliki riwayat penyakit, dan tidak merokok. Pendataan subjek dilakukan di Puskesmas Halmahera, Puskesmas Tlgosari Wetan, dan Puskesmas Kedungmundu. Data yang diambil seperti identitas subjek meliputi 
nama dan alamat, usia ibu hamil, usia kandungan. Jumlah subjek yang didapatkan dari skrinning sebanyak 208 orang. Sampel dipilih dengan menggunakan metode purposive sampling sebanyak jumlah sampel minimal yaitu 44 orang.

Variabel dalam penelitian ini meliputi variabel bebas, variabel terikat, dan variabel perancu. Variabel bebas yaitu status gizi sebelum hamil, asupan karbohidrat, protein, asam lemak omega-3, asam lemak omega-6, dan vitamin B6, variabel terikat yaitu hiperemesis gravidarum, dan variabel perancu yaitu graviditas dan paritas.

Data asupan diperoleh dengan melakukan wawancara menggunakan formulir semi-quantitative food frequency questionnaire (SQ-FFQ). Data asupan hasil wawancara dengan SQ-FFQ tersebut kemudian diolah menggunakan program nutrisurvey. Kebutuhan energi ibu hamil dihitung dengan menggunakan rumus Harris Benedict. Berdasarkan Angka Kecukupan Gizi 2013, cut off point asupan asam lemak omega 3 sebesar 1,4 gr, asupan asam lemak omega 6 sebesar $14 \mathrm{gr}$, dan asupan vitamin B6 sebesar 1,7 gr. Masing-masing asupan tergolong kurang apabila $<80 \%$, tergolong cukup apabila 80 $100 \%$ dan tergolong lebih apabila $>100 \%$.

Data antropometri meliputi berat badan sebelum hamil, berat badan saat hamil, tinggi badan, dan lingkar lengan atas (LiLA) diperoleh dengan pengukuran menggunakan timbangan digital, microtoise, dan pita ukur. Status gizi sebelum hamil dikategorikan dikategorikan underweight apabila
IMT $<17 \mathrm{~kg} / \mathrm{m}^{2}$ dan normal apabila IMT $\geq 17-23$ $\mathrm{kg} / \mathrm{m}^{2}$.

Data mual dan muntah diperoleh melalui wawancara. Mual dan muntah pada ibu hamil dikategorikan hiperemesis apabila frekuensi muntah dalam satu hari $\geq 3$ kali dan bukan hiperemesis gravidarum apabila frekuensi muntah dalam satu hari <3 kali dalam 1 bulan terakhir. ${ }^{16}$

Data yang diperoleh kemudian dianalisis dengan menggunakan program komputer. Analisis univariat digunakan untuk mendeskripsikan masingmasing variabel. Data diuji normalitasnya menggunakan uji Saphiro-Wilk $(\mathrm{n}<50)$ dengan nilai kemaknaan $\mathrm{p}>0,05$. Analisis bivariat pada asupan protein di uji menggunakan uji Chi-square sedangkan status gizi sebelum hamil, asupan karbohidrat, lemak jenuh, asam lemak omega 3, asam lemak omega 6, dan vitamin B6 di uji menggunakan uji Fisher's untuk menganalisis besar risiko masing-masing variabel terhadap kejadian hiperemesis pada ibu hamil.

\section{HASIL}

\section{Karakteristik Subjek Penelitian}

Jumlah subjek pada penelitian ini berjumlah 44 subjek yang terdiri dari 22 subjek pada masingmasing kelompok. Metode pengambilan sampel pada kelompok kasus dilakukan dengan metode purposive sampling. Subjek pada kelompok kontrol dipilih dengan melakukan matching usia subjek, usia kandungan, dan jumlah janin yang dikandung dari kelompok kasus.

Tabel 1. Karakteristik Subjek Penelitian

\begin{tabular}{|c|c|c|c|c|c|c|}
\hline \multirow{2}{*}{ Variabel } & \multicolumn{3}{|c|}{ Hiperemesis $(n=22)$} & \multicolumn{3}{|c|}{ Tidak Hiperemesis $(\mathrm{n}=22)$} \\
\hline & Mean \pm SD & Minimum & Maximum & Mean \pm SD & Minimum & Maximum \\
\hline Usia (Tahun) & $28,59 \pm 3,87$ & 21 & 35 & $27,32 \pm 4,15$ & 21 & 34 \\
\hline Usia Kehamilan (Minggu) & $14,95 \pm 3,99$ & 8 & 24 & $18,5 \pm 5,87$ & 7 & 24 \\
\hline Graviditas (Kali) & $2,18 \pm 1,22$ & 1 & 5 & $1,95 \pm 0,95$ & 1 & 4 \\
\hline Paritas (Kali) & $1,05 \pm 1,13$ & 0 & 4 & $0,91 \pm 0,86$ & 0 & 3 \\
\hline \multicolumn{7}{|c|}{ Frekuensi Mual Muntah (Kali/hari) } \\
\hline Trimester 1 & $4,14 \pm 0,90$ & 3 & 5 & $1,17 \pm 0,98$ & 0 & 2 \\
\hline Trimester 2 & $4,80 \pm 1,69$ & 3 & 7 & $0,62 \pm 0,71$ & 0 & 2 \\
\hline IMT Sebelum Hamil $\left(\mathrm{Kg} / \mathrm{m}^{2}\right)$ & $23,21 \pm 4,29$ & 16,59 & 33,73 & $22,56 \pm 5,04$ & 15,62 & 34,05 \\
\hline \multicolumn{7}{|l|}{ Kecukupan Zat Gizi } \\
\hline Karbohidrat (gr) & $184,6 \pm 76,38$ & 26,86 & 310,83 & $160,71 \pm 53,39$ & 48,63 & 258,57 \\
\hline Protein $(g r)$ & $53,18 \pm 25,47$ & 2,6 & 101 & $46,99 \pm 17,44$ & 12,76 & 77,77 \\
\hline Lemak Jenuh (gr) & $16,12 \pm 9,62$ & 1,78 & 39,34 & $12,86 \pm 5,50$ & 3,44 & 26,47 \\
\hline Omega 3 (gr) & $0,63 \pm 0,42$ & 0 & 1,48 & $0,63 \pm 0,44$ & 0,03 & 1,99 \\
\hline Omega 6 (gr) & $3,11 \pm 2,24$ & 0,05 & 9,03 & $4,15 \pm 4,59$ & 0,43 & 21,99 \\
\hline Vitamin B6 (gr) & $1,10 \pm 0,74$ & 0,03 & 3,36 & $0,78 \pm 0,33$ & 0,20 & 1,52 \\
\hline
\end{tabular}

Tabel 1 menunjukkan karakteristik subjek penelitian pada kedua kelompok. Rerata IMT sebelum hamil, kecukupan asupan karbohidrat, protein, lemak jenuh, dan vitamin B6 pada kelompok kasus lebih tinggi daripada kelompok kontrol. Sedangkan rerata kecukupan asupan asam lemak omega 3 sama untuk kedua kelompok, serta omega 6 lebih tinggi pada kelompok kontrol dibandingkan kelompok kasus. 
Berdasarkan tabel 2, status gizi subjek yang tergolong berstatus gizi kurang (underweight) dengan IMT $<17 \mathrm{~kg} / \mathrm{m}^{2}$ sebesar 9,09\%, subjek dengan status gizi normal sebesar $59,1 \%$, dan sisanya berstatus gizi lebih (overweight dan obese) sebesar $31,8 \%$. Sebanyak $79,5 \%$ subjek memiliki asupan karbohidrat dalam kategori kurang. Asupan protein hampir semua subjek $(68,1 \%)$ berada dalam kategori rendah sedangkan sebanyak $77,3 \%$, asupan lemak jenuh subjek sudah termasuk dalam kategori rendah. Hampir semua subjek $(86,4 \%)$ memiliki asupan asam lemak omega 3 lebih rendah dari yang dianjurkan. Sebanyak 97,7\% subjek mengkonsumsi asam lemak omega 6 dalam jumlah yang rendah. Sedangkan untuk asupan vitamin B6 sebanyak 84\% subjek masih mengkonsumsi vitamin B6 dalam jumlah yang rendah dari yang dianjurkan.

Faktor Risiko Status Gizi Sebelum Hamil, Asupan Karbohidrat, Protein, Lemak Jenuh, Asam Lemak Omega 3, Asam Lemak Omega 6, dan Vitamin B6 dengan Kejadian Hiperemesis Gravidarum

Berdasarkan Tabel 3, hasil analisis bivariat menunjukkan bahwa status gizi sebelum hamil, asupan karbohidrat, protein, lemak jenuh, asam lemak omega 3, asam lemak omega 6 dan vitamin B6 bukan merupakan faktor risiko terjadinya hiperemesis pada ibu hamil di Semarang.

\section{PEMBAHASAN}

Hasil penelitian ini menunjukkan status gizi sebelum hamil, asupan karbohidrat, protein, lemak jenuh, asam lemak omega 3, asam lemak omega 6 , dan vitamin B6 bukan meruakan faktor risiko terjadinya hiperemesis gravidarum pada ibu hamil di Semarang.

Berdasarkan hasil penelitian, status gizi sebelum hamil bukan merupakan faktor risiko terjadinya hiperemesis. Hasil penelitian menunjukkan sebanyak 20,9\% memiliki status gizi sebelum hamil dalam kategori underweight. Penelitian Lagiou et al dan Gul Kiziltan et al. menunjukan bahwa status gizi sebelum kehamilan bukan faktor penentu terjadinya hiperemesis $(p>0,05) \cdot{ }^{17,18}$ Berdasarkan penelitian tersebut, semua kategori IMT pada kelompok hiperemesis memiliki frekuensi muntah yang tinggi. ${ }^{18}$

Hampir semua subjek pada kedua kelompok masih mengkonsumsi karbohidrat dalam jumlah yang rendah $(77,3 \%)$. Hal ini disebabkan karena data asupan subjek diperoleh dalam rentang waktu 1 bulan sebelum wawancara dilakukan sehingga besar kemungkinan selama 1 bulan terakhir subjek sudah mengalami mual dan muntah. Kondisi ini menyebabkan asupan subjek berkurang terutama asupan makanan pokok. Walaupun kedua kelompok hampir semuanya mengkonsumsi karbohidrat dalam jumlah rendah, namun persentase asupan karbohidrat lebih tinggi pada kelompok kasus. Penelitian menunjukkan bahwa konsumsi karbohidrat dalam jumlah tinggi dapat meningkatkan risiko terjadinya hiperemesis, terutama konsumsi karbohidrat dengan tambahan gula. Konsumsi karbohidrat dapat menyebabkan disritmia lambung yang pada akhirnya menyebabkan mual dan muntah. ${ }^{7}$ Namun penelitian lain menunjukan bahwa asupan karbohidrat dapat memicu mual muntah atau dapat mengurangi mual muntah masih belum diketahui. $^{8}$

Tabel 2. Gambaran Usia Kehamilan, Gravida, Paritas, Status Gizi Sebelum Hamil, Kecukupan Asupan Karbohidrat, Protein, Lemak Jenuh, Asam Lemak Omega 3, Asam Lemak Omega 6, dan Vitamin B6 Subjek

\begin{tabular}{|c|c|c|}
\hline Karakteristik & $\mathbf{n}$ & $\%$ \\
\hline \multicolumn{3}{|l|}{ Usia Kehamilan } \\
\hline Trimester 1 & 13 & 29,5 \\
\hline Trimester 2 & 31 & 70,5 \\
\hline \multicolumn{3}{|l|}{ Gravida } \\
\hline Primigravida & 16 & 36,4 \\
\hline Secundigravida & 16 & 36,4 \\
\hline Multigravida & 12 & 27,3 \\
\hline \multicolumn{3}{|l|}{ Paritas } \\
\hline Nulipara & 16 & 36,4 \\
\hline Primipara & 18 & 40,9 \\
\hline Multipara & 10 & 22,7 \\
\hline \multicolumn{3}{|c|}{ Status Gizi Sebelum Hamil } \\
\hline Underweight & 4 & 9,09 \\
\hline Normal & 26 & 59,1 \\
\hline Overweight & 7 & 15,9 \\
\hline Obese & 7 & 15,9 \\
\hline \multicolumn{3}{|l|}{ Asupan Karbohidrat } \\
\hline Tinggi & 1 & 2,3 \\
\hline Normal & 8 & 18,2 \\
\hline Rendah & 35 & 79,5 \\
\hline \multicolumn{3}{|l|}{ Asupan Protein } \\
\hline Rendah & 30 & 68,1 \\
\hline Normal & 12 & 27,2 \\
\hline Tinggi & 2 & 4,5 \\
\hline \multicolumn{3}{|l|}{ Asupan Lemak Jenuh } \\
\hline Tinggi & 5 & 11,4 \\
\hline Normal & 5 & 11,4 \\
\hline Rendah & 34 & 77,3 \\
\hline \multicolumn{3}{|c|}{ Asupan Asam Lemak Omega 3} \\
\hline Rendah & 38 & 86,4 \\
\hline Normal & 4 & 9,1 \\
\hline Tinggi & 2 & 4,5 \\
\hline \multicolumn{3}{|c|}{ Asupan Asam Lemak Omega 6} \\
\hline Tinggi & 1 & 2,3 \\
\hline Rendah & 43 & 97,7 \\
\hline \multicolumn{3}{|l|}{ Asupan Vitamin B6 } \\
\hline Rendah & 37 & 84,0 \\
\hline Normal & 4 & 9,0 \\
\hline Tinggi & 3 & 6,8 \\
\hline
\end{tabular}


Tabel 3.Analisis Bivariat Hubungan Status Gizi Sebelum Hamil, Asupan Karbohidrat, Protein, Lemak Jenuh, Asam Lemak Omega 3, Asam Lemak Omega 6, Vitamin B6 dan Variabel Perancu dengan Kejadian Hiperemesis

\begin{tabular}{|c|c|c|c|c|c|c|}
\hline \multirow[t]{2}{*}{ Variabel } & \multicolumn{2}{|c|}{$\begin{array}{l}\text { Hiperemesis } \\
\quad(n=22)\end{array}$} & \multicolumn{2}{|c|}{$\begin{array}{c}\text { Tidak } \\
\text { Hiperemesis } \\
(\mathbf{n}=22)\end{array}$} & \multirow[t]{2}{*}{$p$} & \multirow[t]{2}{*}{ OR $(95 \% \mathrm{CI})$} \\
\hline & $\mathbf{n}$ & $\%$ & $\mathbf{n}$ & $\%$ & & \\
\hline \multicolumn{7}{|l|}{ Status Gizi Sebelum Hamil } \\
\hline Underweight & 1 & $4,5 \%$ & 3 & $13,6 \%$ & $0,60^{\mathrm{b}}$ & $0,30(0,02-$ \\
\hline Normal & 21 & $95,5 \%$ & 19 & $86,4 \%$ & & $3,15)$ \\
\hline \multicolumn{7}{|l|}{ Asupan Karbohidrat } \\
\hline Tinggi & 1 & $4,5 \%$ & 0 & $0 \%$ & $1,00^{\mathrm{b}}$ & - \\
\hline Normal & 21 & $95,5 \%$ & 22 & $100 \%$ & & \\
\hline \multicolumn{7}{|l|}{ Asupan Protein } \\
\hline Rendah & 13 & $59,1 \%$ & 17 & $77,2 \%$ & $0,19^{\mathrm{a}}$ & $0,42(0,11-$ \\
\hline Normal & 9 & $40,9 \%$ & 5 & $22,7 \%$ & & $1,57)$ \\
\hline \multicolumn{7}{|l|}{ Asupan Lemak Jenuh } \\
\hline Tinggi & 4 & $18,2 \%$ & 1 & $4,5 \%$ & $0,34^{\mathrm{b}}$ & $4,66(0,47-$ \\
\hline Normal & 18 & $81,8 \%$ & 21 & $95,5 \%$ & & $45,62)$ \\
\hline \multicolumn{7}{|l|}{ Asupan Omega 3} \\
\hline Rendah & 19 & $86,3 \%$ & 20 & $90,9 \%$ & $1,00^{\mathrm{b}}$ & $0,63(0,09-$ \\
\hline Normal & 3 & $13,6 \%$ & 2 & $9,1 \%$ & & $4,21)$ \\
\hline \multicolumn{7}{|l|}{ Asupan Omega 6} \\
\hline Tinggi & 0 & $0 \%$ & 1 & $4,5 \%$ & $1,00^{\mathrm{b}}$ & - \\
\hline Normal & 22 & $100 \%$ & 21 & $95,5 \%$ & & \\
\hline \multicolumn{7}{|l|}{ Asupan Vit B6 } \\
\hline Rendah & 17 & $77,2 \%$ & 20 & $90,9 \%$ & $0,41^{\mathrm{b}}$ & $0,34(0,05-$ \\
\hline Normal & 5 & $22,7 \%$ & 2 & $9,09 \%$ & & $1,98)$ \\
\hline \multicolumn{7}{|l|}{ Gravida } \\
\hline Primigravida & 8 & $36,4 \%$ & 8 & $36,4 \%$ & $1,00^{\mathrm{a}}$ & $1,00(0,29-$ \\
\hline Multigravida & 14 & $63,6 \%$ & 14 & $63,6 \%$ & & $3,41)$ \\
\hline \multicolumn{7}{|l|}{ Paritas } \\
\hline Nulipara & 8 & $36,4 \%$ & 8 & $36,4 \%$ & $1,00^{\mathrm{a}}$ & $1,00(0,29-$ \\
\hline Multipara & 14 & $63,6 \%$ & 14 & $63,6 \%$ & & $3,41)$ \\
\hline
\end{tabular}

Sebanyak $70,5 \%$ subjek mengkonsumsi protein dalam jumlah yang rendah. Hal ini dikarenakan sumber protein yang paling banyak dikonsumsi oleh subjek bersumber dari protein nabati daripada protein hewani. Pemilihan makanan yang dikonsumsi subjek dipengaruhi oleh berbagai faktor salah satunya peningkatan sensitifitas subjek terhadap bau dan rasa. Beberapa subjek mengaku mual apabila mencium bau amis pada produk hewani sehingga subjek cenderung menghindari konsumsi produk hewani untuk mengurangi rasa mual. ${ }^{19}$

Sumber protein hewani mengandung rasio protein/energi yang lebih banyak dibandingkan dengan sumber protein nabati. Sumber protein hewani mengandung semua 9 asam amino dan disebut sebagai protein lengkap, sedangkan protein nabati mengandung asam amino esensial tertentu yang lebih rendah terutama lisin, metionin, sistein, dan threonin. Walaupun kedelai termasuk dalam sumber protein nabati, terkadang kedelai juga dianggap sebagai sumber protein lengkap, namun secara keseluruhan kandungan asam amino esensial pada kedelai cenderung rendah. ${ }^{20}$ Protein sangat penting dikonsumsi oleh ibu hamil dalam jumlah cukup. Protein diperlukan untuk menunjang perkembangan jaringan janin. Asupan protein yang tidak memenuhi kebutuhan dapat menyebabkan gangguan pertumbuhan intrauterin dan berat badan lahir rendah, yang dapat meningkatkan risiko morbiditas dan mortalitas bayi serta dapat berdampak pada penyakit kronis pada kehidupan selanjutnya. ${ }^{21}$

Hasil penelitian ini tidak sejalan dengan penelitian sebelumnya dimana kelompok wanita dengan mual dan muntah memiliki asupan protein yang lebih rendah. Meskipun rerata konsumsi protein pada kelompok kasus lebih tinggi, namun rerata konsumsi lemak juga lebih tinggi pada kelompok tersebut. Makanan yang berlemak dapat menunda pengosongan lambung karena lemak dapat menghambat kinerja protein dalam melepaskan gastrin didalam perut. ${ }^{12}$ Protein dapat mencegah terjadinya disritmia lambung karena protein dapat merangsang sekresi gastrin lebih banyak dibandingkan dengan zat gizi lainnya. Pencernaan 
protein dapat menghasilkan peptida dan asam amino yang mana dapat menstimulasi sekresi gastrin. Gastrin dapat meningkatkan aktivitas lambung normal dan berirama dengan mengikat otot polos antral. Gastrin juga memiliki efek stimulasi langsung pada otot polos lambung melingkar, dan efek tidak langsung pada otot longitudinal lambung. ${ }^{9}$

Hasil penelitian menunjukkan bahwa asupan lemak jenuh bukan merupakan faktor risiko terjadinya hiperemesis. Hal ini sejalan dengan penelitian Kiziltan et al. yang menunjukkan bahwa tidak ada hubungan antara asupan lemak jenuh dengan risiko hiperemesis gravidarum, walaupun tingkat konsumsi lemak jenuh pada kelompok hiperemesis lebih tinggi dibandingkan dengan kelompok tanpa hiperemesis. ${ }^{18}$ Sebanyak 79,5\% subjek sudah mengkonsumsi lemak jenuh dalam jumlah rendah, namun persentase asupan lemak jenuh lebih tinggi pada kelompok kasus. Hal ini dikarenakan subjek yang mengalami mual dan muntah cenderung tidak memiliki nafsu makan dan mengkonsumsi beberapa sumber lemak jenuh seperti produk susu dan biskuit sebagai pengganti nasi saat lapar, serta es krim untuk mengurangi rasa mual dan mengkonsumsi lauk pauk dengan cara digoreng dengan menggunakan minyak kelapa sawit. ${ }^{22}$ Lemak jenuh juga dispekulasikan dapat meningkatan produksi estrogen melalui konversi steroid menjadi estradiol melalui enzim aromatase. ${ }^{10}$ Tingginya kadar estrogen menyebabkan waktu transit usus lebih lambat dan dapat menghambat pengosongan lambung. ${ }^{5}$

Penelitian yang dilakukan oleh Haugen et al. menunjukkan bahwa tidak ada perbedaan asupan asam linolenat, EPA, DHA, dan asam linoleat pada kelompok wanita dengan hiperemesis dan kelompok wanita tanpa hiperemesis. ${ }^{11}$ Pada penelitian ini juga tidak ada perbedaan rerata konsumsi asam lemak omega 3 pada kedua kelompok. Dari 44 subjek, sebanyak 56,8\% subjek masih mengkonsumsi asam lemak omega 3 dalam jumlah yang rendah dan sebanyak $97,7 \%$ subjek mengkonsumsi asam lemak omega 6 dalam jumlah yang rendah. Hal ini dikarenakan masyarakat cenderung lebih banyak mengkonsumsi ikan air tawar dibandingkan ikan laut. Penelitian di Nigeria menunjukkan bahwa ikan laut memiliki kandungan asam lemak omega 3 yang lebih tinggi dibandingkan ikan air tawar. Kandungan asam lemak yang berbeda antara ikan air tawar dan ikan laut dapat disebabkan oleh beberapa faktor eksternal seperti lingkungan, metode budidaya, dan iklim, sedangkan faktor internal meliputi spesies ikan, pola makan dan pencernaan, siklus hidup, karakteristik kuantitatif dan kualitatif lipidtriasilgliserol, fosfolipid, dan asal topografi. ${ }^{23}$ Hanya 1 subjek yang mengkonsumsi asam lemak omega 6 dalam jumlah tinggi. Hal ini dikarenakan subjek gemar mengkonsumsi kacang tanah. Dalam 100 gram kacang tanah mengandung 15,7 gram asam lemak omega $6 .{ }^{24}$ Jumlah ini sudah melebihi kebutuhan asam lemak omega 6 pada ibu hamil yang hanya 13 gram, sedangkan dalam 1 hari subjek dapat mengkonsumsi sekitar 148 gram kacang tanah.

Eicosapentaenoic acid (EPA) dan docosahexaenoic acid (DHA) merupakan komponen bioaktif utama asam lemak tak jenuh omega-3 yang harus diperoleh secara langsung dari makanan, terutama konsumsi ikan. Asupan asam lemak omega 3 penting bagi ibu hamil untuk menunjang berat badan lahir dan meminimalisir risiko bayi lahir prematur. Banyak ibu hamil baik negara dengan pendapatan rendah, menengah, dan tinggi masih mengkonsumsi asam lemak omega 3 terutama DHA dalam jumlah yang rendah, kecuali negara pesisir dimana ikan dan makanan laut lainnya dapat diakses secara mudah. ${ }^{25}$ Kurangnya konsumsi DHA mempengaruhi stabilitas membran neuron dan transmisi serotonin, norepinefrin, dan dopamin yang berhubungan dengan mood dan disfungsi kognitif. Serotonin juga berperan dalam mencegah terjadinya mual dan muntah. Selain itu, EPA juga diperlukan untuk menyeimbangkan fungsi kekebalan dan kesehatan fisik dengan menekan efek proinflamasi asam arakhidonat sehingga mengurangi sintesis prostaglandin E2. Prostaglandin E2 dinilai turut berperan dalam patogenesis mual dan muntah pada ibu hamil karena efeknya pada kontraksi otot polos longitudinal dan relaksasi otot polos melingkar. ${ }^{13,26}$

Pada penelitian ini semua asupan lemak termasuk lemak jenuh, asam lemak omega 3, dan asam lemak omega 6 bukan merupakan faktor risiko hiperemesis. Hal ini dapat disebabkan karena metode pengambilan data yang digunakan dalam penelitian ini adalah food frequency questionnaire (FFQ). Sebuah artikel menunjukkan bahwa metode FFQ dinilai kurang tepat dalam menggambarkan asupan lemak jangka panjang karena panjang dan kurang akurat dibandingkan dengan pengukuran asam lemak eritrosit yang dapat menggambarkan kebiasaan asupan lemak dari makanan sehari-hari serta kadar EPA untuk penanda spesifik asupan ikan dan minyak ikan. ${ }^{27}$ Asam lemak omega 3 dan omega 6 penting untuk dikonsumsi secara seimbang. Beberapa pendapat mengemukakan bahwa rasio omega 6:omega 3 sebesar 4:1 dapat mengurangi risiko mortalitas sebesar $70 \%$, namun ada juga beberapa peneliti yang berpendapat rasio ideal omega 6:omega 3 adalah 1:1 atau 2:1. Studi menyebutkan bahwa ibu hamil berisiko mengalami depresi apabila rasio konsumsi omega 6:omega 3 melebihi 9:1.28,29 
Sebanyak 84\% subjek masih mengkonsumsi vitamin B6 dalam jumlah yang rendah dari makanan sehari-hari. Rendahnya konsumsi vitamin B6 jarang terjadi sendiri dan sering berhubungan dengan defisiensi vitamin B kompleks. Rendahnya asupan vitamin B6 dapat menyebabkan preeklamsia, intoleransi karbohidrat, hiperemesis gravidarum, dan gangguan syaraf pada bayi. Defisiensi vitamin B6 juga dapat berdampak pada imunitas. ${ }^{30}$ Hasil penelitian ini menunjukkan vitamin B6 bukan merupakan faktor risiko terjadinya hiperemesis. Penelitian yang dilakukan oleh Roudlotul Jannah menunjukkan asupan vitamin B6 tidak berhubungan dengan kejadian mual muntah pada ibu hamil trimester pertama. Hal ini dikarenakan kejadian mual muntah pada ibu hamil tidak hanya disebabkan oleh asupan vitamin B6 tetapi juga dipengaruhi oleh faktor lainnya. Selain itu, bioavailabilitas vitamin B6 hanya berkisar 50-58\% untuk bahan makanan nabati dan sekitar $75 \%$ untuk bahan makanan campuran nabati dan hewani sehingga jumlah vitamin B6 yang dikonsumsi dari makanan sehari-hari tidak seluruhnya dapat diserap oleh tubuh. ${ }^{31}$

Penelitian sebelumnya menunjukkan bahwa primigravida, nulipara dan primipara lebih berisiko untuk mengalami hiperemesis. ${ }^{32,33}$ Namun pada penelitian ini pada kedua kelompok tidak ada perbedaan graviditas dan paritas, serta baik paritas maupun graviditas bukan merupakan faktor risiko terjadinya hiperemesis. Penelitian oleh Matsuo menunjukkan tidak ada perbedaan graviditas dan paritas pada kelompok hiperemesis dan tanpa hiperemesis $(p=0,84 ; p=0,21)$. Penelitian tersebut juga menunjukkan bahwa primipara bukan faktor risiko terjadinya hiperemesis $(\mathrm{OR}=1.05 ; 95 \% \mathrm{CI}$ $0.73-1.52$ ).

Semua variabel bebas bukan merupakan faktor risiko hiperemesis gravidarum pada ibu hamil di Semarang. Hal ini dapat disebabkan karena pembagian kelompok pada penelitian ini memiliki karakteristik yang hampir sama antara kelompok kasus dan kelompok kontrol. Selain itu, hiperemesis sendiri merupakan multifaktoral meliputi faktor biologis, psikologis, dan sosiokultural sehingga tidak hanya disebabkan oleh faktor asupan.

\section{SIMPULAN}

Sebagian besar ibu hamil memiliki status gizi sebelum hamil yang normal namun memiliki asupan zat gizi yang masih rendah dari yang dianjurkan. Status gizi sebelum hamil, asupan karbohidrat, protein, lemak jenuh, asam lemak omega 3, asam lemak omega 6, dan vitamin B6 bukan merupakan faktor risiko terjadinya hiperemesis gravidarum pada ibu hamil di Semarang.
Ibu hamil dalam penelitian ini dianjurkan untuk mengkonsumsi makanan yang beragam untuk memenuhi kebutuhan zat gizi baik untuk ibu hamil maupun untuk janin terutama protein serta asam lemak omega 3 dan asam lemak omega 6 dalam jumlah cukup untuk menunjang pertumbuhan dan perkembangan janin. Bagi penelitian selanjutnya, dapat dilakukan pembagian kelompok berdasarkan karakteristik yang lebih spesifik untuk memperoleh hasil perbedaan yang signifikan.

\section{UCAPAN TERIMAKASIH}

Terimakasih kepada seluruh responden dan semua pihak yang telah berpartisipasi dalam penelitian ini.

\section{DAFTAR PUSTAKA}

1. Ricci SS, Kyle T. Maternity and Pediatric Nursing. 2009.

2. Orshan SA. Maternity, Newborn, and Women's Health Nursing: Comprehensive Care Across the Life Span. Lippincott William \& Wilkins; 2008.

3. Birkeland E, Stokke G, Tangvik RJ, Torkildsen EA, Boateng J, Wollen AL, et al. Norwegian PUQE ( Pregnancy-Unique Quantification of Emesis and Nausea ) Identifies Patients with Hyperemesis Gravidarum and Poor Nutritional Intake: A Prospective Cohort Validation Study. 2015;(May 2013):1-15.

4. Ziomkiewicz A, Ellison PT, Lipson SF, Thune I, Jasienska G. Body Fat, Energy Balance and Estradiol Levels: A Study Based on Hormonal Profiles from Complete Menstrual Cycles. Hum Reprod. 2008;23(11):2555-63.

5. Bajaj S, Rajput R, Jacob JJ. Endocrine Disorders During Pregnancy. Jaypee Brothers Medical Publishers; 2013.

6. Huo L, Li B, Wei F. Maternal Nutrition Associated with Nausea and Vomiting During Pregnancy: A Prospective Cohort China Study. 2017;

7. Chortatos A, Haugen M, Iversen PO, Vikanes A, Magnus P. Nausea and vomiting in pregnancy: associations with maternal gestational diet and lifestyle factors in the Norwegian Mother and Child Cohort Study. 2013;1642-53.

8. Green MN. Nausea, pregnancy sickness and the role of dietary protein. 2010;1-21.

9. Stern RM, Koch KL, Andrews P. Nausea: Mechanisms and Management. Oxford University Press; 2011. 288 p.

10. Rippe JM. Lifestyle Medicine. Taylor and Francis Group; 2013. 292 p.

11. Haugen $\mathrm{M}$, Brantsæter $\mathrm{AL}$, Meltzer HM, Grjibovski AM. Diet before pregnancy and the risk of hyperemesis gravidarum. 2017;(2011):596-602.

12. Levine ME, Muth ER, Williamson MJ, Stern RM. 
Protein-predominant Meals Inhibit The Development of Gastric Tachyarrhythmia, Nausea and The Symptoms of Motion Sickness. Aliment Pharmacol Ther. 2004;19(5):583-90.

13. Su K. Biological Mechanism of Antidepressant Effect of Omega - 3 Fatty Acids : How Does Fish Oil Act as a ' Mind-Body Interface '? 2009;14452.

14. Wibowo N, Purwosunu Y, Sekizawa A, Farina A, Tambunan V, Bardosono S. Vitamin B6 Supplementation in Pregnant Women with Nausea and Vomiting. Int $\mathbf{J}$ Gynecol Obstet [Internet]. 2012;116(3):206-10. Available from: http://dx.doi.org/10.1016/j.ijgo.2011.09.030

15. Fibriana AI. Faktor-Faktor Risiko yang Mempengaruhi KematianMaternal (Studi Kasus di Kabupaten Cilacap). Program. 2007;79.

16. Niemeijer MN, Grooten IJ, Vos N, Bais JMJ, Post JA Van Der, Mol BW, et al. Diagnostic Markers for Hyperemesis Gravidarum: Systematic Review and Metaanalysis. 2014;(August).

17. Lagiou P, Tamimi R, Mucci LA, Trichopoulos D, Adami HO, Hsieh CC. Nausea and vomiting in pregnancy in relation to prolactin, estrogens, and progesterone: A prospective study. Obstet Gynecol. 2003;101(4):639-44.

18. Kiziltan G, Saka M, Turker P, Ercan A. Dietary and Other Factors As Risks of Hyperemesis Gravidarum. HealthMED. 2012;6.

19. Weigel MM, Coe K, Castro NP, Caiza ME, Tello N, Reyes M. Food Aversions and Cravings During Early Pregnancy: Association with Nausea and Vomiting. Ecol Food Nutr. 2011;50(3):197214.

20. Gilbert JA, Bendsen NT, Tremblay A, Astrup A. Effect of proteins from different sources on body composition. Nutr Metab Cardiovasc Dis. 2011;21(SUPPL. 2).

21. Buttriss JL, Welch AA, Kearney JM, LanhamNew SA. Public Health Nutrition. John Wiley \& Sons; 2017.

22. Tuminah S. Efek Asam Lemak Jenuh dan Asam Lemak Tak Jenuh "Trans" Terhadap Kesehatan. Media Penelit dan Pengemb Kesehat [Internet]. 2009;XIX(Suplemen II):S13-20. Available from: http://bpk.litbang.depkes.go.id/index.php/MPK/ar ticle/viewFile/751/1685.

23. UGOALA CHUKWUEMEKA, NDUKWE G.I, AUDU T.O. Comparison of Fatty Acids Profile of Some Freshwater and Marine Fishes. Internet J Food Saf. 2008;10(January 2008):9-17.
24. Sandefur HN, McCarty JA, Boles EC, Matlock MD. Peanut Products as a Protein Source [Internet]. Sustainable Protein Sources. Elsevier Inc.; 2016. 209-221 p. Available from: http://dx.doi.org/10.1016/B978-0-12-8027783.00013-5

25. Imhoff-Kunsch B, Briggs $\mathrm{V}$, Goldenberg $\mathrm{T}$, Ramakrishnan U. Effect of n-3 long-chain polyunsaturated fatty acid intake during pregnancy on maternal, infant, and child health outcomes: A systematic review. Paediatr Perinat Epidemiol. 2012;26(SUPPL. 1):91-107.

26. Lee. N., Saha S. Nausea and Vomiting of Pregnancy. Gastroenterol Clin north am. 2011;40(2):1-27.

27. Zamaria N. Alteration of Polyunsaturated Fatty Acid Status and Metabolism in Health and Disease. Most. 2004;44:219-31.

28. Gómez Candela C, Bermejo López LM, Loria Kohen V. Importance of A Balanced Omega 6/Omega 3 Ratio for The Maintenance of Health. Nutritional Recommendations. Nutr Hosp. 2011;26(2):323-9.

29. Da Rocha CMM, Kac G. High Dietary Ratio of Omega-6 to Omega-3 Polyunsaturated Acids During Pregnancy and Prevalence of Post-partum Depression. Matern Child Nutr. 2012;8(1):36-48.

30. Lapido OA. Nutrition in Pregnancy: Mineral and Vitamin Supplements. Am J Clin Nutr [Internet]. 2000;72(1 SUPPL.):280S-290S. Available from: http://www.embase.com/search/results?subaction =viewrecord $\&$ from=export $\& \mathrm{id}=\mathrm{L} 30439800 \% 5 \mathrm{Cn}$ http://sfx.library.uu.nl/utrecht?sid=EMBASE\&iss $\mathrm{n}=00029165 \& \mathrm{id}=\mathrm{doi}: \&$ atitle $=$ Nutrition $+\mathrm{in}+$ pregn ancy $\% 3 \mathrm{~A}+$ Mineral+and+vitamin+supplements\&s title $=$ Am.. J.+Clin. + Nutr.\&title $=$ Americ

31. Jannah R. Asupan Vitamin B6 dan Kejadian Mual Muntah Pada Ibu Hamil Trimester Pertama. 2008;

32. Hailemariam Segni et al. Prevalence of Hyperemesis Gravidarum and Associated Factors Among Pregnant Women at Jimma University Medical Center, South West Ethiopia: A CrossSectional Study. EC Gynaecol. 2016;5:376-87.

33. Roseboom TJ, Ravelli ACJ, Van Der Post JA, Painter RC. Maternal characteristics largely explain poor pregnancy outcome after hyperemesis gravidarum. Eur J Obstet Gynecol Reprod Biol [Internet]. 2011;156(1):56-9. Available from: http://dx.doi.org/10.1016/j.ejogrb.2011.01.010 